\title{
1. Introduction: researching international law and peace
}

\author{
Cecilia M. Bailliet
}

'We are a world in pieces. We need to be a world at peace.'

UN Secretary-General Antonio Guterres

\section{INTRODUCTION}

Peace is an inherently elusive concept, varying in its definition and valuation according to historical epoch and contextual application within different cultures, institutions, civil society groups, and academic disciplines. ${ }^{1}$ It is especially vague within the realm of international law. One of the most prominent and influential scholars in international law, Hersch Lauterpacht, famously stated in the wake of World War II that international law should be functionally oriented towards both the establishment of peace between nations and the protection of fundamental human rights'. ${ }^{2}$ Yet, while the protection of human rights steadily gained support as a primary purpose of international law, international legal literature largely abandoned promoting the establishment of peace as a public good or independent, overarching aim of international law. ${ }^{3}$ One factor is that international law has been marked by the dominance of positivist approaches to law and fragmentation into technical sub-fields, such as trade law, international humanitarian law, etc. which avoid reflection on broader values, including peace. The chapters in this book assess to what extent are international institutions oriented towards the aim of peace and what are the primary challenges of implementation in policy and practice? We propose that the acknowledgement of peace as a primary, common function of international institutions indicates a potential for greater interaction between different legal fields, thereby diminishing fragmentation.

Another factor is that there is a trend towards normalization of violence as a tradition within international law, to the detriment of non-violent dispute resolution mechanisms.

1 On the different meanings of peace, see Ian M. Harris, 'Peace Education Theory', Journal of Peace Education 1 (2004), 7.

2 Hersch Lauterpacht, 'The Grotian Tradition in International Law', British Yearbook of International Law 23 (1946), 1, 51.

3 The most significant text that sought to pursue law as the key to implementation of peace was Grenville Clark and Louis B. Sohn, World Peace Through World Law (Cambridge: Harvard University Press 1958, 1960, 1966). See also Grenville Clark and Louis B. Sohn, Introduction to World Peace Through World Law (Cambridge: Harvard University Press 1984). See also Hans Kelsen, Peace Through Law (The Lawbook Exchange Ltd 2008). See also James T. Ranney, 'World Peace Through Law-Rethinking an Old Theory', CADMUS Journal 1 (2012), 125. 


\section{Research handbook on international law and peace}

This is made evident by an excessive focus by academics and policy makers on the use of force, for example: self-defence operations, humanitarian interventions, peace enforcement missions, and counter-terror/counter-insurgency strategies that use targeted killings and drone strikes as modes of operation. ${ }^{4}$ It is claimed that in recent years, 'wars' are no longer called wars and the use of peace treaties has declined, in part in order to avoid the risk of accountability of leaders for war crimes. ${ }^{5}$ Most armed conflicts are characterized as being primarily intrastate, in spite of the complicated engagement of external actors in provision of weapons, financing, etc. The lack of clarity in defining the boundaries and types of armed conflict under international law also affects how the international community responds to the challenge of peacemaking and peace-building. ${ }^{6}$ There is a need to re-direct the orientation of legal research to tackle the construction and implementation of peace as the central puzzle, removing it from the periphery.

This Research Handbook responds to the gap created by the neglect of peace within mainstream international law scholarship. In order to discuss how international law relates to peace, it offers a working definition of what is meant by peace and calls for further research by legal scholars. The book supports the view that the law of peace is not merely rhetorical, but instead material. It explains the range of hard and soft law normative instruments relevant to peace within international law, as well as the variety of institutional and structural mechanisms designed for implementation, identifying predicaments and opportunities for improvement.

At present, the international community is currently seeking to define new strategies to address global challenges, i.e. increased migration, terrorism, inequality, and cyber insecurity that affect peace. This is complicated by a recent paradigm shift in geopolitics as the international community is moving towards what may be considered a Post-Western Age that entreats renewed attention to the relation between international law and peace. The Western Age and Liberal Peace Model are characterized by the promotion of a free-market economy, representative democracy, human rights, and the

4 See Christine Gray, The Use of Force (Oxford: Oxford University Press, 4th edn 2018); Tom Ruys, Oliver Corten, and Alexandra Huner, The Use of Force in International Law: A Case Based Approach (Oxford: Oxford University Press 2018); Christine Chinkin and Mary Kaldor, International Law and New Wars (Cambridge: Cambridge University Press 2017). See also Davis Brown, 'Contemporary International Law on the Decision to Use Armed Force', in The Ashgate Research Companion to Military Ethics, James Johnson and Eric Patterson (eds) (Routledge 2016), 37. See also Christian Hendersen, The Persistent Advocate and the Use of Force: The Impact of the United States Upon the Jus Ad Bellum in the Post-cold War Era (Routledge 2016).

5 Tanisha M. Fazal, 'The Demise of Peace Treaties in Interstate War', International Organizations 67 (Fall 2003), 697. She notes that of 64 interstate wars fought in the 20th century, only 23 were accompanied by formal peace treaties. (698). Nevertheless, Christine Bell states that: 'between 1990 and September 2007, 646 documents which could lay claim to the name peace agreement were signed, addressing 102 inter- and intra-state conflict dyads spanning 85 jurisdictions'. Christine Bell, On the Law of Peace: Peace Agreements and the Lex Pacificatoria (Oxford: Oxford University Press 2008), 5.

6 See Bettina Scholdan, 'The End of Active Hostilities: The Obligation to Release Conflict Internees Under International Law', Case W. Res. J. Int'l L. (Winter 2016), 15. 
rule of law. ${ }^{7}$ The Post-Western Age is marked by a tendency towards authoritarian capitalism, 'sovereign democracy' (where the state controls expression, assembly, association), and 'rule of law' programmes to battle corruption and crime through state action, rather than separation of powers. ${ }^{8}$

In 2017, Freedom House reported that enjoyment of political and civil rights around the world had deteriorated to its lowest point in the past 12 years. ${ }^{9}$ That same year, the UN Secretary-General, Antonio Guterres, set forth a UN reform initiative that seeks to reinforce 'our ability to safeguard people's peace, security, and human rights' ${ }^{10}$ Three months later, the UN High Commissioner for Human Rights, Zeid Ra'ad al-Hussein announced that he would not seek a second term due to his concern that he would be granted less independence under the current geopolitical context in which states seek to stifle criticism of infringements on human rights. There is a worldwide sense of crisis that creates a demand for emergency security responses that negatively impact human rights and deflect attention from long term legal approaches oriented towards peace. ${ }^{11}$ The foundation of human rights is weakening and this raises the question as to whether peace is subject to similar devaluation. This book contains chapters that suggest that human rights remain relevant to peace: as an element by which to measure the risk of conflict, as a regime by which measure the effectiveness of transition to peace or consolidation of peace, and as a normative form of expression of peace itself. This book seeks to promote reflection on the importance of orienting legal research towards creative re-imagination of the potential for international law and its various institutions to achieve the common aim of constructing and consolidating peace.

The Introduction is divided into separate sections - Section 2 addresses the definition of negative and positive components of peace and sets forth the state of art within the field. Section 3 describes the central importance of peace within the UN Charter, and Section 4 provides an overview of the chapters in the book while also identifying additional research issues relating to international law and peace that are not addressed in the present volume.

7 See Russel Buchan, International Law and the Construction of the Liberal Peace (Oxford: Hart 2013).

8 Amitay Acharya, The End of American World Order (Polity Press 2014) and O. Stuenkel, Post Western World (Polity 2016).

9 https://freedomhouse.org/report/freedom-world/freedom-world-2018\#fiw-key-findings (accessed 21 June 2018). It estimated that only 39 per cent of the world population can be considered to be free.

10 UN Secretary General Address to the UN General Assembly, 19 September 2017, available at: https://www.un.org/sg/en/content/sg/speeches/2017-09-19/sgs-ga-address (accessed 21 June 2018).

11 Dianne Otto, Remapping Crisis through a Feminist Lens (February 16, 2011). Univ. of Melbourne Legal Studies Research Paper No. 527. 


\section{DEFINITION OF THE NEGATIVE AND POSITIVE COMPONENTS OF PEACE AND STATE OF THE ART}

\subsection{Definition of Negative and Positive Peace}

Peace is a multifaceted concept that lacks clear definition and boundaries. Considerable scholarly attention within peace research has been devoted to attempting to illuminate its scope and content, but no universally accepted definition has emerged. However, for the purposes of the present book, it is useful to focus on two important components of peace.

The first component of peace is that of negative peace, which may be characterized as the absence of war or armed conflict. If there is no war, there is peace. In international law such a dichotomy can be traced all the way back to Hugo Grotius' fundamental distinction between 'the law of war' and 'the law of peace'. ${ }^{12}$ The negative peace approach focuses on the prevention of armed conflict; it advocates non-violent dispute resolution and condemns the unlawful use of force or violence. Traditionally, it has generally applied at the international level referring to interstate relations, but it is now increasingly directed also at intrastate armed conflict and violence. ${ }^{13}$

The majority of peace research has focused on this negative component of peace, more specifically on the prevention of war or violence. ${ }^{14}$ Yet, even in relation to negative peace there is a significant range of approaches, which can be categorized according to their emphasis on pacifism. Principled pacifism is the absolute belief in non-aggression and non-violence with no exceptions permitted whatsoever. It is based on moral-religious or secular (deontological) values. ${ }^{15}$ Realistic pacifism, on the other hand, accepts exceptions, primarily those contained within the UN Charter, i.e. the use of force in self-defence in accordance with Article 51 or with an authorization from the UN Security Council under Chapter VII. Within realistic pacifism there are divided opinions regarding the possibility of other exceptions from the prohibition on the use of force, primarily regarding the legality and legitimacy of humanitarian intervention and the status of the controversial doctrine on the 'Responsibility to Protect' (R2P). ${ }^{16}$ A third category, namely contingent/conditional/selective pacifism, evaluates jus ad bellum and/or jus in bello and/or jus post bellum in order to oppose particular armed conflicts, such as those involving weapons of mass destruction, or those that violate the

12 Hugo Grotius, De Jure Belli ac Pacis (1625).

13 See Oliver Corten, The Law Against War: The Prohibition on the Use of Force in Contemporary International Law (Oxford: Hart 2012).

14 Nils Petter Gleditsch, Jonas Nordkvelle, and Håvard Strand, 'Peace Research—Just the Study of War', Journal of Peace Research 54 (2014).

15 For an overview of pacifism see the Stanford Encyclopedia of Peace, http://plato. stanford.edu/entries/pacifism/ (accessed 21 June 2018).

16 See Kjell Anderson, 'The Universality of War: Jus Ad Bellum and the Right to Peace in Non-International Armed Conflicts', in The Challenge of Human Rights: Past, Present and Future, David Keane and Yvonne McDermott (eds) (Cheltenham: Edward Elgar 2012). See also the chapters by Pål Wrange and Ola Engdahl in the present volume. 
UN Charter. ${ }^{17} \mathrm{~A}$ fourth category, prudential pacifism, involves the pragmatic concern for the cost/waste of war; it is consequentialist in orientation and may have particular relevance in this time of economic/financial crisis that may limit military options from a fiscal perspective. ${ }^{18}$

The present book does not advocate principled pacifism, nor is it primarily concerned with selective or prudential pacifism. This book rests on the unequivocal premise that the UN Charter's system, i.e. the prohibition on the use of force in Article 2(4) with two explicit exceptions from that prohibition, is a fundamental element of international law that this book does not set out to revise. In terms of negative peace, the book applies instead a concept of realistic pacifism (as described above), meaning that the chapters within this book set out to explain how international law promotes a realistic peace.

The second component of peace is a broader conception, namely positive peace. While negative peace refers to the 'absence of' something (namely war and violence), positive peace refers to the 'presence of' something. As articulated by Galtung, positive peace calls for the presence of cooperation between people and states and the 'integration of human society'; incorporating social justice (equal opportunity/enjoyment of social contract/human dignity), respect for human rights, and the elimination of 'structural violence' which causes poverty, inequality, exclusion, death, or disability through inequitable distribution of resources addressing basic human needs (such as food, medicine, housing), or denial of equal protection when addressing domestic violence, hate crimes, etc. ${ }^{19}$ It may apply to both intrastate and interstate relations. Galtung intended this concept to shift attention away from the East-West Cold War tension in favour of addressing the North-South divide (although one may argue that we may be returning to a new variation of East-West friction). ${ }^{20}$ Nevertheless, this perspective was criticized for being aligned with Neo-Marxism. ${ }^{21}$ An apparent consequence was that international legal scholars largely shied away from peace studies, in part due to the fear of association with pro-communist or pro-Soviet sympathies, and in part on account of concern that the scope of positive peace was too broad, pursuing utopianism. ${ }^{22}$ Thus, peace research returned to the negative orientation of preventing war and violence. To the extent it addressed cooperation, it focused on how it might reduce

17 See Leonard Hammer, 'Selective Conscientious Objection and International Human Rights', Israel Law Review 36 (2002).

18 As noted by Mary Ellen O'Connell: '(T)he next development will simply be toward using less expensive force-think drone attacks and Stuxnet worms'. 'Energized by War Fatigue', ESIL Reflections (2014), http://www.esil-sedi.eu/node/522 (accessed 21 June 2018).

19 E.g. Johan Galtung, 'Violence, Peace, and Peace Research', Journal of Peace Research 6 (1969), 167-91. Structural violence refers to the phenomenon of social structures or social institutions inflicting harm upon people by preventing them from meeting their basic needs.

20 Gleditsch et al. supra note 14.

21 Ibid.

22 Edward Gordon, Book Review: 'From Erasmus to Tolstoy: The Peace Literature of Four Centuries; Jacob Ter Meulen's Bibliographies of the Peace Movement Before 1899', Harvard International Law Journal 34 (1993), 641. 


\section{Research handbook on international law and peace}

violence, thereby falling in line with liberal peace theory. ${ }^{23}$ This theory emphasizes state consent to institutions and legal regimes that create rules intended to promote harmonized interests based on shared norms and principles; thereby limiting state sovereignty and resort to military power in the interest of establishing a peaceful international order through cooperation. ${ }^{24}$ Liberalism emphasizes the recognition of individuals as primary actors in society; further it supports tolerance, diversity, equal opportunity, freedom, the rule of law, institutional reform, free elections, and free markets. ${ }^{25}$ At present, liberalism is in decline in part due to the rise of nativism, authoritarianism, and populism. ${ }^{26}$ This is exemplified by the phenomenon of 'democratatorships'/'democraduras' which are characterized by maintenance of elections (real or sham) but also pursue repression of freedom of expression, association, etc.

Current trends in resurgent violence around the world have various manifestations, including terrorism, criminal based violence (including gang related violence), inter and intra based proxy warfare, ethnic and religion rivalry based violence, gender based violence; as well as structural elements and symptoms, such as competition for water/land, unemployment, and forced internal and external migration. ${ }^{27}$ The sense of global insecurity is increased by the continuous state of cyberwarfare without regulation within international law. ${ }^{28}$ The search for solutions requires creative approaches which break with prior crisis-oriented security perspectives and instead are oriented towards long-term, positive peace aspirations - 'sustainable peace', in keeping with the UN Sustainable Development Goals. ${ }^{29}$ As we move towards a Post-Western Age, it is a question as to how to construct the international law of peace because 'peace' (including the right to peace) may be considered non-justiciable, and hence may not be incorporated within domestic systems, thereby affecting implementation.

Human rights, in particular, first generation rights (e.g. civil and political rights addressing freedom of expression, assembly, and association) were articulated as

23 See Michael Doyle, Liberal Peace: Selected Essays (New York: Routledge 2011) and John MacMillan, On Liberal Peace: Democracy, War and the International Order (London: Tauris Academic Studies 1998). See also the chapter by Kristoffer Lidén and Henrik Syse in the present volume.

24 Gleditsch et al. supra note 14. On liberalism in international relations, see Anne L. Herbert, 'Cooperation in International Relations: A Comparison of Keohane, Haas and Franck', Berkeley Journal of International Law 14 (1996), 222.

25 For a critical view of liberal peace see Roger MacGinty, International Peacebuilding and Local Resistance: Hybrid Forms of Peace (New York: Palgrave 2011), 26.

26 See Peter S. Goodman, 'The Post-World War II Order is Under Assault from the Powers that Built it', The New York Times (28 March 2018), available at: https://www.nytimes.com/2018/ 03/26/business/nato-european-union.html (accessed 4 July 2018).

27 See The World Bank, Pathways For Peace: Inclusive Approaches to Preventing Violent Conflict (2017). See also the Uppsala Conflict Data Program, available at: http://www.uu.se/en/ news-media/news/article/?id=10996\&area=2,6,10,16,25,46\&typ=artikel\&lang=en (accessed 21 June 2018) the majority of armed conflicts between non-state groups occurred in Africa in 2017.

28 See the Tallinn Manual on Cyberwarfare: https://www.peacepalacelibrary.nl/ebooks/files/ 356296245.pdf (accessed 21 June 2018).

29 The UN Development Goals: https://www.un.org/sustainabledevelopment/sustainabledevelopment-goals/ (accessed 21 June 2018). 
fundamental values as part of Western Soft Power. ${ }^{30}$ Second generation socio-economic rights (such as the right to an adequate standard of living, education, food, water, and health) were more often treated as non-justiciable interests to be addressed in a progressive manner via a state's long-term development policies. Third generation collective rights (such as a healthy environment, development, and peace) were regarded as merely moral aspirations. This is in spite of the fact that feminists argued in favour of recognition of second and third generation rights, including the right to food, gender equality, and peace as jus cogens. ${ }^{31}$ From a human rights perspective, the move towards a Post-Western Age signals a possible shift away from civil and political rights towards socio-economic rights and third generation rights, including the right to peace. ${ }^{32}$

Further, there appears to be a shift from the liberal, individual autonomy orientation towards a communitarian approach. This supports recognition of moral duties owed to collective groups, such as refugees/migrants, minorities, children, and women. ${ }^{33}$ Non-Western states are favourable to realization of collective rights as a means of attaining stability. ${ }^{34}$ The US has stated that a shift to a collective right to peace may carry the risk of stifling human rights (e.g. freedom of expression). ${ }^{35}$ A counter-view is that renewed attention to solidarity approaches will actually render human rights more universal, precisely by being inclusive of the values reflective of the East and the South. Hence, there are tensions arising from different conceptions of what is the relationship between the aim of peace and the realization of human rights.

This Handbook suggests that the Post-Western Age is marked by a displacement of legal fields: human rights that were a key element of Western Soft Power are being supplanted by increased attention to international economic law, counter-terrorism, and cyber security as regimes which are relevant to promoting peace. Further, the Post-Western Age may prompt a displacement of law: the Western Age placed emphasis

30 J. Nye, Soft Power: The Means to Success in World Politics (New York: Public Affairs 2004).

31 Hilary Charlesworth and Christine Chinkin, 'The Gender of Jus Cogens', Human Rights Quarterly 15:63 (1993).

32 See UN Human Rights Council Resolution 37/13 on the Question of the Realization in All Countries of Economic, Social, and Cultural Rights, A/HRC/RES/37/13 (9 April 2018); see also UN Human Rights Council Resolution 36/9 on The Right to Development, A/HRC/RES/36/9 (6 October 2017); see also UN Human Rights Council, Resolution 35/4 on Promotion of the Right to Peace (22 June 2017).

33 See UN Human Rights Council, Rights of Persons belonging to National or Ethnic, Religious, and Linguistic Minorities, A/HRC/37/L.25 (19 March 2018); UN Human Rights Council, Resolution on From Rhetoric to Reality: A Global Call for Concrete Action Against Racism, Racial Discrimination, Xenophobia, and Related Intolerance, A/HRC/RES/36/24 (9 October 2017); UN Human Rights Council, Resolution 35/10 on Accelerating Efforts to Eliminate Violence Against Women: Engaging Men and Boys in Preventing and Responding to Violence Against All Women and Girls, A/HRC/RES/35/10 (12 July 2017); see also UN Human Rights Council, Resolution 36/5 on Unaccompanied Migrant Children and Adolescents and Human Rights, A/HRC/RES/36/5 (4 October 2017).

34 Sheng Ding, 'Is Human Rights the Achilles' Heel of Chinese Soft Power? A New Perspective on Its Appeal', Asian Perspective 36:4 (2012), 641-65.

35 https://geneva.usmission.gov/2013/06/13/eov-on-the-right-to-peace/ (accessed 21 June 2018). 


\section{Research handbook on international law and peace}

on justiciable rights regarding freedom of expression, religion, and property. Current initiatives appear to promote non-justiciable rights related to socio-economic and collective rights, such as social justice, human security, sustainable development, and peace as the relevant norms. This implies that implementation of positive peace or 'sustainable peace' may take a different form. Indeed the World Bank published a report, Pathways for Peace, that stated:

The best way to prevent societies from descending into crisis - including but not limited to conflict - is to ensure they are resilient through investment in inclusive and sustainable development. For all countries, addressing inequalities and exclusion, making institutions more inclusive, and ensuring that development strategies are risk-informed are central to preventing the fraying of the social fabric that could erupt into crisis. ${ }^{36}$

Nevertheless, international law has suffered from a systemic blind spot as pertaining positive peace. Trade and investment institutions are facing legitimacy crises due to their failure to integrate elements of positive peace and cyber security is largely oriented towards prevention of attacks (negative peace), thus it has also largely ignored positive peace. Immigration, Border Control, and Refugee processing institutions, as well as NGOs present in refugee camps, are increasingly concerned with countering violent extremism among refugees and identifying those linked to terrorism, thereby also focusing on negative peace. Mediation institutions are being encouraged to diminish their focus on human rights and instead focus on violence prevention. These trends underscore a need to identify and explore positive peace approaches.

\subsection{State of the Art}

There has been recent renewed attention on peace by American and European legal scholars which continue to focus primarily on negative peace, such as: Mary Ellen O'Connell, Robert Kolb, and Oliver Corten (prohibition of the use of force), Georg Nolte (ed.) (state responsibility and the role of the ILC), Christine Bell (on peace treaties, 'lex pacificatoria' - jus post bellum/post-conflict law), Carsten Stahn (jus post bellum), Christine Chinkin and Mary Kaldor, Russell Buchan (on liberal peace, peacekeeping, peace-building, and occupation) and James Ranney (on the abolition of nuclear weapons, international dispute resolution, and a UN peace force). ${ }^{37}$

36 The World Bank, Pathways for Peace: Inclusive Approaches to Preventing Violent Conflict (2017), 3 .

37 Mary Ellen O'Connell, 'Peace and War' in The Oxford Handbook of the History of International Law, B. Fassbender and A. Peters (eds) (Oxford: Oxford University Press 2012), 272; Robert Kolb, International Law on the Maintenance of Peace: Jus Contra Bellum (Cheltenham: Edward Elgar 2018); Georg Nolte (ed.), Peace through International Law: The Role of the International Law Commission (Springer 2009); Christine Bell, On the Law of Peace: Peace Agreements and the Law Pacificatoria (Oxford: Oxford University Press 2008); C. Bell, 'Of Jus Post Bellum and Lex Pacificatoria: What's in a Name?' (June 19, 2013). Chapter 10, in Ius Post Bellum: Mapping the Normative Foundations, Carsten Stahn, Jennifer S. Easterday, and Jens Iverson (eds) (Oxford: Oxford University Press 2014), 181-206; Christine Chinkin and Mary Kaldor, 'The Liberal Peace: Peacemaking, Peacekeeping and Peacebuilding' in Chinkin and Kaldor, supra note 4 at 374-429; Russel Buchan, International Law and the 
On positive peace, there is less literature by legal scholars, and it tends to focus on post-conflict peace initiatives: for example, Tuba Turan (on pursuing positive peace through conflict prevention, peacekeeping, and peace-building by the UN), and Martin Wählisch (negative and positive peace: on peace agreements, power sharing, and human rights). ${ }^{38}$ This literature reveals the potential of peace related legal research to expand in range and depth. Since the emerging literature on positive peace remains largely oriented toward conflict prevention/resolution, there is a knowledge gap regarding its application within other international legal fields, such as economic law or cyber law. There is a need for peace research to evolve beyond the focus on conflict prevention and resolution in order to provide holistic approaches to the construction and implementation of the international law of peace in the Post-Western Age. This Research Handbook calls for a conceptual change in how legal academics understand peace in order to open up new horizons for peace through law research worldwide.

This Research Handbook is not limited to a negative concept of peace. Instead, the authors adopt a broad definition of peace that includes a wide-ranging, positive dimension. ${ }^{39}$ Although peace research commenced with the incentive to prevent nuclear war; at present one may argue that the looming, gradual cataclysm presented by climate change, a marked increase in inequality in the world, and the phenomenon of failing and failed states require a reorientation of academic focus. ${ }^{40}$ There is also a juxtaposition of concern for the inequitable consequences of globalization with the increased attention on the situation and role of individuals, groups, and other non-state actors such as corporations. ${ }^{41}$ Hence, peace may be situated within the micro level of home and family, centring on interpersonal relations and the requirements of human dignity as an element of peace; as well as at the macro level, exploring the aspiration of equality between states and peoples. ${ }^{42}$ This book discusses how international law promotes the establishment and protection of relevant criteria pertaining to social

Construction of the Liberal Peace (Oxford: Hart 2013); J.T. Ranney, World Peace through Law (Routledge 2018); Heinz G. Justenhoven, Claus Kress, and Mary Ellen O'Connell (eds) Peace Through Law: Reflections on Pacem in Terris from Philosophy, Law, Theology, and Political Science (Nomos/Bloomsbury 2016); and Oliver Corten, The Law Against War, supra note 13.

38 T. Turan, Positive Peace in Theory and Practice: Strengthening the United Nations' Pre-Conflict Prevention Role (Brill 2016); M. Wahlisch, Peacemaking, Power Sharing, and International Law: Imperfect Peace (Oxford: Hart 2018).

39 On the hybridity of negative and positive peace, see Oliver Richmond, A Post-Liberal Peace (London: Routledge 2011).

40 See Rafael Domingo, The New Global Law (Cambridge: Cambridge University Press 2011); A.A. Cancado Trindade, International Law for Humankind, Towards a New Jus Gentium (Leiden: Martinus Nijhoff 2010). Nonetheless, concern for increased nuclear weapon proliferation remains heightened, in spite of the adoption of the Treaty on the Prohibition of Nuclear Weapons in 2017, see Eric Schlosser, 'The Growing Dangers of the New Nuclear Arms Race', The New Yorker (May 24, 2018).

41 See Cecilia M. Bailliet (ed.), Non-State Actors, Soft Law and Protective Regimes (Cambridge: Cambridge University Press 2012).

42 On the micro level, see Karen Warren and Duane L. Cady (eds), Bringing Peace Home: Feminism, Violence and Nature (Indiana University Press 1996); on the macro level, see Gerry Simpson, Great Powers and Outlaw States Unequal Sovereigns in the International Legal Order (Cambridge: Cambridge University Press 2004). 
justice, such as non-discrimination and equality. The chapters also address the link between negative and positive peace by discussing the normative and institutional frameworks addressing prevention of war and violence, the promotion of sustainable development, and the protection of human rights, underscoring the holistic purposes articulated in UN Charter, Article 1:

1. To maintain international peace and security, and to that end: to take effective collective measures for the prevention and removal of threats to the peace, and for the suppression of acts of aggression or other breaches of the peace, and to bring about by peaceful means, and in conformity with the principles of justice and international law, adjustment or settlement of international disputes or situations which might lead to a breach of the peace;

2. To develop friendly relations among nations based on respect for the principle of equal rights and self-determination of peoples, and to take other appropriate measures to strengthen universal peace;

3. To achieve international cooperation in solving international problems of an economic, social, cultural, or humanitarian character, and in promoting and encouraging respect for human rights and for fundamental freedoms for all without distinction as to race, sex, language, or religion; and

4. To be a centre for harmonizing the actions of nations in the attainment of these common ends.

Students of international law are very familiar with a holistic interpretation of negative and positive rights in the field of human rights law, and this book applies a similar framework for negative and positive elements in the concept of peace - this handbook treats these elements as indivisible, interrelated, and interdependent. ${ }^{43}$

\section{THE LAW OF PEACE ACCORDING TO THE UN CHARTER}

The modern emergence of the law of peace is derived from various instruments that articulate a notion of peace as relating to interstate relations setting forth the prohibition of unlawful use of force and promotion of the use of dispute settlement mechanisms to avoid breaches of the peace, inter alia: the Briand-Kellogg Pact which condemned 'recourse to war for the solution of international controversies' (1928), the Hague Convention of 1899 which established the Permanent Court of Arbitration, the Hague Convention of 1907 which resulted in the Convention on the Pacific Settlement of International Disputes, and the Covenant of the League of Nations (1919). ${ }^{44}$ Foremost at present is the UN Charter; the Preamble states that the peoples of the UN have determined:

43 See Asbjørn Eide, 'Interdependence and Indivisibility of Human Rights', in Human Rights in Education, Culture and Science: Legal Developments and Challenges, Vladimir Volodin and Yvonne Donders (eds) (Aldershot: Ashgate 2007), 11-52.

44 See Oona A. Hathaway and Scott J. Shapiro, The Internationalists and their Plan to Outlaw War (Allen Lane 2017). 
- to practice tolerance and live together in peace with one another as good neighbours, and

- to unite our strength to maintain international peace and security, and

- to ensure, by the acceptance of principles and the institution of methods, that armed force shall not be used, save in the common interest, and

- to employ international machinery for the promotion of the economic and social advancement of all peoples.

Taken together with Article 1(1), (2), and (3), it is noted that "peace is more than the absence of war'. ${ }^{45}$ Article 1 sets forth that the purpose of the UN is to maintain international peace and security, and to that end to take effective collective measures for the prevention and removal of threats to the peace, suppression or acts of aggression or other breaches of the peace, and to bring about by peaceful means ... settlement of international disputes or situations which might lead to a breach of the peace. Article 2(3) states that all members 'shall settle their international disputes by peaceful means in such a manner that international peace and security, and justice, are not endangered'. ${ }^{46}$ Article 2(4) calls upon members to 'refrain in their international relations from the threat or use of force against the territorial integrity or political independence of any state, or in any other manner inconsistent with the Purposes of the United Nations'. The ICJ confirmed this to constitute a jus cogens norm. ${ }^{47}$ Article 2(7) prohibits interference by the UN in domestic affairs:

Nothing contained in the present Charter shall authorize the United Nations to intervene in matters which are essentially within the domestic jurisdiction of any state or shall require the Members to submit such matters to settlement under the present Charter; but this principle shall not prejudice the application of enforcement measures under Chapter VII. ${ }^{48}$

45 Wolfrum Rüdiger, 'Article 1', in The Charter of the United Nations: A Commentary, Bruno Simma, Daniel-Erasmus Khan, Georg Nolte, and Andreas Paulus (eds) (Oxford: Oxford University Press, 3rd edn 2012), 110.

46 See also Chapter VI, Article 33: 'The parties to any dispute, the continuance of which is likely to endanger the maintenance of international peace and security, shall, first of all, seek a solution by negotiation, enquiry, mediation, conciliation, arbitration, judicial settlement, resort to regional agencies or arrangements, or other peaceful means of their own choice.'

47 Military and Paramilitary Activities in and against Nicaragua (Nicaragua v. United States) (Judgment) [1984] ICJ. (Henceforth Nicaragua v. United States). As noted by Mary Ellen O'Connell, 'States employing armed force in violation of Article 2(4) have not claimed that Article 2(4) does not exist or is not binding, but rather have attempted to validate their behavior by claiming that they are actually acting in compliance with Article 2(4) and the exceptions for self-defence or invitation.' Mary Ellen O'Connell, The Power and Purpose of International Law: Insights from the Theory and Practice of Enforcement (Oxford: Oxford University Press 2008), 169.

48 D. Gilmour, "The Meaning of "Intervene" within Article 2(7) of the United Nations Charter-An Historical Perspective', International and Comparative Law Quarterly 16:2 (1967), 330-51. See L. Howard and A. Dayal. 'The Use of Force in UN Peacekeeping', International Organization 72:1 (2018), 71-103. 


\section{Research handbook on international law and peace}

It is of significant concern that the War on Terror has prompted an increased application of Chapter VII enforcement mechanisms, including targeted sanctions against individuals and counter-terrorist operations utilizing force, raising human rights concerns. 49

It is noteworthy that membership in the UN is open to all other peace-loving states which accept the obligations contained in the present Charter and, in the judgment of the Organization, are able and willing to carry out these obligations'. 50 It has been remarked that the 'peace-loving' criterion 'refers both to their past and present conduct'. ${ }^{51}$ This was originally interpreted to include states that had engaged in the war against the Axis powers or had a non-Fascist past and also interpreted to preclude states that had governments that had been supported by the Axis powers (Spain). Of interest, at the time of the San Francisco conference, 'peace-loving' was not to be defined by reference to the internal level of democracy, because this would constitute unlawful interference in internal affairs. Yet, over time, references to democracy were made by Western countries when discussing the applications of Central and Eastern European nations. States are generally considered 'peace-loving' by reviewing their external, international behaviour: 'including compliance with UN resolutions, guaranteeing innocent passage in territorial waters, settling border disputes peacefully, and respecting the principle of non-intervention' ${ }^{52}$

Nonetheless, the UN Charter does not espouse a principled, absolutist version of pacifism. ${ }^{53}$ It is a pragmatic document that reflects realistic pacifism as it recognizes the exceptions of individual and collective self-defence against an 'armed attack' and protection of others, in accordance with Article 51 and Chapter VII, Article 42, as an

49 Chinkin and Kaldor, supra note 4 at 175-225 and Gray, supra note 4. See Devon Whittle, 'The Limits of Legality and the United Nations Security Council: Applying the Extra-Legal Measures Model to Chapter VII Action', European Journal of International Law 26:3 (1 August 2015), 671-98.

501945 United Nations Charter, Article 4(1).

51 Ulrich Fastenrath, 'Article 4', in Simma, Khan, Nolte, and Paulus (eds), supra note 45, 348.

52 Ibid.

53 Hedley Bull characterizes peace to be a goal of the society of states, not universal and permanent peace, but rather 'the maintenance of peace in the sense of the absence of war among member states of international society as the normal condition of their relationship, to be breached only in special circumstances and according to principles that are generally accepted'. Hedley Bull, The Anarchical Society (New York: Columbia University Press, 4th edn 1995), 17. Hence, it may be argued that the international community is torn between the notion that war is an institution of international society or that it is 'a pathological occurrence in international dealings, leading to utterly inhuman behavior'. See Antonio Cassese, Paola Gaeta, Laura Baig, Mary Fan, Christopher Gosnell, and Alex Whiting, Cassese's International Criminal Law (Oxford: Oxford University Press, 3rd edn 2013), 63. It is notable that the realistic perspective appears to have ancient roots, as Fatiha Sahli and Abdelmalek El Ouazzani remark that 'For the Muslims, peace, in theory could not be permanent. It was limited in time and appears like a truce which could not exceed a period of ten years.' Fatiha Sahli and Abdelmalek El Ouazzani, 'Africa North of the Sahara and Arab Countries', in The Oxford Handbook of The History of International Law, Bardo Fassbender and Anne Peters (eds) (Oxford: Oxford University Press 2012), 402. 
enforcement measure at the direction of the UN Security Council; it has also been interpreted to support humanitarian intervention and self-determination movements. ${ }^{54}$ As pointed out by Mónica García-Salmones, 'The maxim of "peace through law" goes, structurally, hand in hand with the maxim of "war through law". 55 The expansive interpretation of the exceptions has been applied in a wide range of scenarios, as observed by Christine Chinkin and Mary Kaldor:

In the twenty-first century setting, the interpretation of the right to self-defence has been stretched to cover responses to attacks by non-state actors $(9 / 11$, IS) defence of non-state entities (South Ossetia), protection of nationals abroad (Georgia, Ukraine), protection against internal attacks (Yemen) as well as in anticipation (pre-emption) of external attacks (Iraq and Afghanistan). ${ }^{56}$

This trend along with evolving doctrines such as the 'Responsibility to Protect' have resulted in divisions between many Western/Northern governments (which state they are seeking to prevent and respond to mass atrocities and humanitarian disasters that may be considered 'threats to peace'); as opposed to Eastern/Southern governments which staunchly contest the legitimacy of these actions and call for strengthened respect for the fundamental principle of non-intervention as contained in Article 2(7) of the UN Charter. ${ }^{57}$ The fact that Africa has accepted humanitarian intervention within its constitutive act demonstrates a shift towards increased recognition of R2P theory,

54 See generally Corten, supra note 13. See also Nicaragua v. United States case, in which the ICJ confirmed the right to self-defence as a rule of customary international law. See also Ben Kioko, 'The Right of Intervention under the African Union's Constitutive Act: From Noninterference to Non-intervention', International Review of the Red Cross 85 (2003), 807-26. See also Gray, supra note 4 at 196. She identifies two opposing views: those who view collective self-defence as a means to help weak states from oppression, and those who consider this a threat to world peace as it may foment inter-state conflicts.

55 Mónica García-Salmones, 'Walter Schucking and the Pacifist Traditions of International Law', European Journal of International Law 22 (2011), 767.

56 Chinkin and Kaldor, supra note 4 at 173. Consider the debate regarding 'Article 51 letters' from states (e.g. the United States, Belgium, United Kingdom, Germany, Norway) to the UN Security Council arguing that because Syria was unwilling or unable to prevent ISIS from making attacks from its territory, there was grounds for recognition of the principle of self-defence to justify use of military force in Syria. See Oliver Corten, 'The "Unwilling or Unable" Test: Has it Been, and Could it be, Accepted?', Leiden Journal of International Law 29:3 (2016), 777-99. See also Marko Milanovic, 'Belgium's Article 51 Letter', on EJIL Talk!, available at: https://www.ejiltalk.org/belgiums-article-51-letter-to-the-security-council/ (accessed 19 June 2018). See also, Cecilia M. Bailliet, 'The "Unrule" of Law: Unintended Consequences of Applying the Responsibility to Prevent to Counterterrorism, A Case Study of Colombia's Raid in Ecuador', in Security: A Multidisciplinary Normative Approach Cecilia, M. Bailliet (ed.) (Brill 2009), 175.

57 Christine Gray, states: '(I)t is now clear that the R2P doctrine does not include a right of unilateral intervention in the absence of a Security Council authority.' She indicates that some states are concerned about the risk of selective application and abuse by powerful states, given that is unclear who determines the threshold for action. Gray, supra note 4 at 60. 


\section{Research handbook on international law and peace}

but the other regions remain skeptical. ${ }^{58}$ Nevertheless, the struggle to uphold non-intervention as a fundamental principle of international law continues to be emphasized within the policy of Latin America, Russia, and China, albeit with contradictions in actual practice, in part due to emerging concerns for addressing security situations within their 'neighborhoods' ${ }^{59}$

There is concern that there has been a cultural shift in favour of increased resort to military force to resolve conflicts and weakening of non-violent dispute resolution mechanisms, including diplomacy and conciliation, as well as a lack of attention as to urgent need to address structural violence which lies at the foundation of persistent inequality within the world.

The new Declaration on the Right to Peace adopted by the UN General Assembly in 2017 sets forth in its Preamble that a culture of peace is a set of values, attitudes, traditions and modes of behaviour and ways of life ... and that all this should be fostered by an enabling national and international environment conducive to peace. ${ }^{60}$ This Research Handbook seeks to promote legal academic research as having the potential to play an important role in strengthening a culture of peace.

\section{OVERVIEW AND DELIMITATIONS}

As explained above, this book seeks to bridge the gap between negative and positive peace research within the framework of international law. Research of international law and peace requires analysis of the relation between these two notions in the context of specific legal regimes. For example, to what extent are international normative instruments and institutions oriented towards reducing violence, is there a discrepancy

58 See Kioko, supra note 54. See also Spencer Zifcak, 'The Responsibility to Protect' in International Law, Malcolm D. Evans (Oxford: Oxford University Press, 5th edn 2018), 484-515. Zifcak points out that as of October 2017, 114 nations had signed a Security Council code of practice in which they voluntarily agreed not to issue a veto in situations involving genocide, crimes against humanity, or war crimes.

59 See Javier Couso, 'Back to the Future? The Return of Sovereignty and the Principle of Non-Intervention in the Internal Affairs of the States in Latin America's "Radical Constitutionalism"' in Constitutionalism in the Americas, Colin Crawford and Daniel Bonilla Maldonado (eds) (Cheltenham: Edward Elgar 2018). See also A. Kleczkowska, 'The Distinctiveness of the Latin American Security System-Why Is It so Different? Public International Law Perspective' in Cross-Disciplinary Perspectives on Regional and Global Security, P. Frankowski and A. Gruszczak A (eds) (Cham: Palgrave Macmillan 2018). See also Roy Allison, 'Russia and the Post-2014 International Legal Order: Revisionism and RealPolitik', International Affairs 93:3 (2017), 519-43; Xiaohong Xu, 'China's Engagement in African Security Affairs in the Post-Cold War Era', International Relations and Diplomacy 5:7 (July 2017), 412-25; Yanzhuo Xu, China, Africa, and Responsible International Engagement (Routledge 2017); Xhongying Pang, 'China's Non-Intervention Question', Global Responsibility to Protect 1:2 (2009), 237-52; Courtney J. Fung, Foreign-Imposed Regime Change and Intervention in Chinese Foreign Policy at the UN Security Council (East Asian Institute Working Paper October 2017).

60 UN General Assembly, Declaration on the Right to Peace: resolution/adopted by the General Assembly, 2 February 2017, A/RES/71/189, available at: http://www.refworld.org/docid/ 589c72134.html (accessed 19 June 2018). 
between policy and practice? The normative frameworks that address the maintenance of peace and security are subject to dilemmas resulting from the controversial doctrine of the 'Responsibility to Protect'. Additionally, there is a shift in the legitimacy of UN mandates that are oriented towards the promotion and protection of social justice, human rights, development at a time when there is a backlash against human rights and global inequality has risen in spite of an increase in global wealth. ${ }^{61}$ Hence, the contributions in this book are divided into four main parts which address the interface between peace, security, justice, human rights, and development from a legal and multidisciplinary perspective, underscoring normative developments and the role of institutions in promoting these aims without advocating a hierarchical order or set causality paradigm. ${ }^{62}$ The chapters present clear dilemmas faced by different governance institutions in meeting the aim of creating peace and underscore the importance of promoting further legal research to resolve constraints and strengthen comprehension of the requirements of peace.

Part I discusses the quandaries revealed by examining the normative scope of peace and its exceptions. There is an overview of the liberal origin of the notion of peace as developed within Western political philosophy and a call for new scholarship from alternative schools of thought. This is followed by a presentation of the normative evolution of the law of peace within international law, both outside of and within the United Nations, and points to support for dispute resolution institutions as a key challenge. The importance of attaining recognition of the duty of states to uphold the obligation to resolve disputes peacefully is underscored as a central principle that has been marginalized in policy and practice, resulting in a weakening of related institutions. ${ }^{63}$ This Part then examines to what extent the notion of collective security is compatible with maintenance of peace, utilizing critical theories from international relations to discuss dilemmas in practice. Finally, the Part concludes with a frank exploration of whether or not it is possible to attain peace through the use of force, in particular analyzing puzzles arising from the controversial 'Responsibility to Protect' doctrine.

In Chapter 2, Kristoffer Lidén and Henrik Syse discuss the origins of a liberal, rights-based conception of peace in the political thought of Hobbes, Locke, and Kant. The chapter outlines how this conception plays out in contemporary perspectives on international law as a source of peace, with a view to the strands of realism, internationalism, and cosmopolitanism. It is demonstrated how the argument for widening the scope of peace in international law beyond the regulation of interstate warfare relates to a liberal cosmopolitan challenge to the Westphalian state system, as defended by internationalism. It also indicates why realists and internationalists would reject such a move and insist on subjecting concerns for peace to the principle of state

61 Glenn-Marie Lange, Quentin Wodon, and Kevin Carey, The Changing Wealth of Nations 2018: Building a Sustainable Future (The World Bank 2018).

62 Variations in causality appear to be context dependent, see Chandra Lekha Sriram, 'Beyond Transitional Justice: Peace, Governance, and Rule of Law', International Studies Review 19:1 (1 March 2017), 53-69.

63 See also Yoshifumi Tanaka, The Peaceful Settlement of International Disputes (Cambridge: Cambridge University Press 2018). 
sovereignty. The chapter does not provide a comprehensive overview of conceptions of peace in international law but focuses on a particular strand of political philosophy associated with 'the liberal peace'. Because this idea has been highly influential in the international politics of peace over the past decades, the argument serves as a vantage point for critical analysis of the presuppositions of contemporary legal debate on peace and conflict. While the argument could be misunderstood as implying that considerations on peace in international law should be limited to a liberal political outlook of a Western kind, the chapter invites responses from non-liberal and non-Western perspectives.

In Chapter 3, Cecilia M. Bailliet traces the evolution of the international law of peace from the notion of a 'right to peaceful coexistence' contained in the Joint Statement on the Promotion of International Law issued by China and Russia in 2016 to the adoption of a Declaration on the Right to Peace by the Third Committee of the UN General Assembly in 2017. The chapter seeks to explain how the right to peace signals a new direction in the evolution of human rights law towards non-justiciable duties in the Post-Western Age. She suggests that it might be beneficial to strengthen institutions addressing the implementation of peace.

Chapter 4, by Cecilia M. Bailliet and Simon O'Connor, addresses the character of the obligations in the UN Charter with respect to the maintenance of international peace and security as articulated in Article 1(1), (2), and (3), and Chapters VI and VIII. This contribution discusses the sequential nature of the Charter to emphasize the obligations, first and foremost, to resolve disputes peacefully and prevent escalation. The chapter presents the framework of UN Bodies, including the Security Council, General Assembly, and office of the Secretary-General and their practice in implementing these obligations. Additionally, it underscores the importance of recourse to these fora in pursuing negotiations between states and non-state actors. Finally, it delineates the role of regional mechanisms in enabling states to fulfil their primary duty of pacific settlement. It concludes by suggesting that implementation of the duty of non-violent dispute resolution should be prioritized by increasing support for existing UN and regional institutions addressing the pacific settlement of disputes.

In Chapter 5, Pål Wrange offers a critical, conceptual analysis of collective security, both in the current UN shape and as a general concept. The basic premise for the chapter is that even though collective security is a fundamental goal of the UN Charter, the collective security system is fraught with many political and practical problems. The chapter analyses a number of conceptual difficulties, but argues that these difficulties do not mean that collective security is impossible. The chapter asks whether collective security could be improved better to maintain international peace and security or if there is an inherent contradiction in the idea. The analysis is informed by critical traditions in international law and international relations.

In Chapter 6, Ola Engdahl discusses how peace, in its various connotations, may be achieved through the use of military force. Protection against grave violations of human rights may also require the use of military force, and the connection between international peace and security and the respect for human rights is evident in the practice of the UN Security Council. The concept of a 'Responsibility to Protect' has grown out of a need to protect against grave violations of human rights when the Security Council has not been able to respond. The ideas behind this concept may thus 
to some extent be described as emphasizing protection of human rights over the prohibition on the use of force - and the maintenance of peace between states. International law does not yet provide a right of states to intervene with military force in another state to protect against human rights violations without a mandate from the UN Security Council, and thus seems to value peace among states more highly than protection against human rights violations. This begs the question how respect for human rights contributes to the maintenance of peace and how peace contributes to the protection of human rights, and, in a longer perspective, whether one could exist without the other.

Part II sets out the contribution of structural approaches to peace and suggests that there is a need for further research on the links between peace, security, stability, sustainable development, and protection of the environment as providing a foundation for 'sustainable peace'. The authors indicate that this type of research requires holistic approaches that are best pursued by merging multidisciplinary frames of analysis.

This Part begins with an examination of the violation of human rights as a risk factor for breaches of peace. This is followed by a chapter that examines structural violence and the challenge of attaining sustainable development in countries undergoing violent conflict. The concept of human rights protection as a foundation of both negative and positive peace is explored. In addition, the section explains the link between peace and other solidarity rights, such as the right to a clean environment. Examination of the role of international investment in supporting sustainable development, preventing conflict, and providing restitution in post-conflict scenarios presents a novel perspective on strategies linked to peacebuilding.

This Part further addresses the challenge of nuclear disarmament and the regulation of the arms trade as one of the primary preconditions for peace that has galvanized peace activists through ages but resulting in contradictory standards within international law. It also explains the potential contribution of the Arms Trade Treaty in supporting peace. A significant concern is that the advancement of technology continues beyond the limits of present international law. For example, neither autonomous weapons nor incendiary weapons are regulated, despite their heavy use. ${ }^{64}$ These chapters provide reflection of the complexity of guaranteeing peace through normative processes.

Hence, this Part provides an overview of the range of issues that benefit from applying a positive peace analysis and examines the benefits and drawbacks of multilateral approaches and the pursuit of cooperation to address global challenges. The approaches may be linked to the UN Sustainable Development Goals and hence offer a blue print for 'sustainable peace' ${ }^{65}$

In Chapter 7, Kjersti Skarstad observes that a central premise and promise of human rights law is that the protection of human rights leads to more peaceful societies. Yet, in empirical conflict research, rights violations have for the most part not been seen as a relevant conflict risk factor. Also within the human rights literature it is unclear why and how violations possibly lead to a higher risk of violent civil conflicts. This chapter

64 Sean Watts, 'Autonomous Weapons: Regulation Tolerant or Regulation Resistant?', Temple International and Comparative Law Journal 30:1 (2016), 177.

65 The UN Sustainable Development Goals: https://www.un.org/sustainabledevelopment/ sustainable-development-goals/ (accessed 19 June 2019). 
explains theoretically how human rights violations can potentially increase the risk of violent civil conflicts. It argues that human rights abuses serve as both conflict facilitators and conflict multipliers. It then demonstrates empirically that violations of basic economic and social rights and physical integrity rights increase the risk of civil war, while the effects of other civil and political rights are minor. The main implication of these results is that human rights policies and the enforcement of human rights law are well worth pursuing in order to reduce conflict risk.

In Chapter 8, Bård A. Andreassen addresses how the doctrine of 'structural violence' refers to violence where social structures, relations, and institutions threaten peoples' basic interests and needs. It is inherently related to social injustices and the failure to fulfil basic human rights The right to development discourse, as it developed in the late 1990s with reference to the UN Declaration on the Right to Development, provides a framework for analysing such structural violence from new perspectives that combine various types of rights in analyzing social injustices, poverty, and 'failed development'. The chapter explores the argument that the main constraint on sustainable development may not be a poverty trap (i.e. that people living in poverty lack capacities and access to productive resources that can enable them to move out of poverty), but rather traps of violence that constrain sustainable development at both macro and micro levels. Lack of functioning legal structures and institutions for rights protection and public policies addressing poverty are important factors explaining the difficulties of escaping poverty.

In Chapter 9, Ole Kristian Fauchald and Daniel Behn explore the long-standing claim and ambition in international law that the juridical settlement of international disputes can and does provide an alternative and more peaceful remedy for conflicts arising between states. In the context of international investment law, claims about the positive benefits that can result from the peaceful settlement of foreign investment disputes are frequently framed as a question about the extent to which these disputes may serve to reduce tensions between states. The idea is that by giving foreign investors direct access to arbitration against states hosting their investments, investment treaty arbitration bypasses the necessity of diplomatic espousal and may diffuse tensions or hostilities that might otherwise arise between home states and host states. In this sense, investment treaty arbitration may remove the power politics and threats of military escalation that were a common feature of foreign investment disputes in the era of 'gunboat diplomacy'. Fauchald and Behn examine whether and how foreign direct investment contributes to peace and sustainable development. They review the respective roles of international investment agreements and investment treaty arbitration in terms of their contribution to peace. These studies focus on three main situations. First, they assess the contribution of investment law to the resolution of disputes related to international and internal armed conflicts. Secondly, they examine how investment law can contribute to peace-building in post-conflict situation. Finally, they explore how investment law can contribute to peace-building more broadly conceived (positive peace). The main findings of the chapter are that international investment law has had very limited peace related functions so far, but that there is a trend and significant potential towards more important contributions in the future.

In Chapter 10, Christina Voigt describes how the protection and preservation of the natural environment, integrity of ecological systems, and the survival of species are 
positive conditions for peace and human security. Given the interdependent and complex nature of the global environment, no state alone can effectively protect it. Rather, global cooperative efforts to reach significant concessions on states' sovereignty to exploit their natural resources are necessary in order to halt, reverse, and prevent environmental degradation. At the same time, environmental protection in order to be a foundation for peace should be aligned with eco-sensitive development needs as aptly expressed in the principle of sustainable development. International environmental law is the branch of international law that aims to translate these conditions in its design, institutions, and implementation. Voigt shows, however, that progress is slow, and that a shift in the quality of international laws is required: a shift that recognizes the fundamental importance of healthy ecological conditions. Such realization requires a new vision of international law and international relations, where a healthy environment is recognized as the foundation for peaceful human societies. This chapter gives an overview over the inter-linkages between environmental protection, sustainable development, and peace. It examines the tools and means of international environmental law in this context and highlights the importance of multilateralism and global cooperation to address these issues. It further studies the particular example of climate change and the multilateral efforts under the UN to establish a collaborative climate effort - based on global equity and sustainable development.

In Chapter 11, Kjølv Egeland examines the relationship between nuclear disarmament and peace, describing it as close but uneasy. On the one hand, nuclear weapons are indiscriminate instruments of mass killing, developed to destroy whole cities. Hence, nuclear disarmament is considered to be a prerequisite of peace in both the positive and negative senses of the term. Yet, on the other hand, some argue that the prospect of a devastating nuclear conflict is precisely the reason major powers have not waged war on each other since 1945. Nuclear weapons, in this view, foster peace. These conflicting understandings of the relationship between nuclear weapons and peace have both found expression in the institutional and legal framework for nuclear arms control and disarmament. While bilateral arms limitation regimes, like SALT, had as their aim not the elimination but the regulation of nuclear-deterrence relations, countless UN General Assembly resolutions have demanded full nuclear disarmament. The 1968 Nuclear Non-Proliferation Treaty, often regarded as the 'cornerstone' of the nuclear regime, prohibits states that had not tested a nuclear weapon by 1 January 1967 from acquiring such arms and commits those that had to 'pursue negotiations' towards - but not necessarily to bring about - nuclear disarmament. In recent years, nonnuclear-weapon states and civil society actors have sought to resolve the apparent contradictions of the nuclear regime by bringing into force a treaty unequivocally prohibiting nuclear weapons.

In Chapter 12, Gro Nystuen and Kjølv Egeland evaluate the potential of the Arms Trade Treaty (ATT) to reduce violations of international humanitarian law and human rights law. The chapter assesses the process and outcome of the negotiations of the ATT, the first international instrument that makes an explicit link between arms export and its potential consequences in terms of violations of international humanitarian law and human rights law. The authors present the negotiation history of the ATT, comparing it to other recent treaty negotiations within humanitarian disarmament, and discuss the association between international law and peace studies. The main aim of 
the chapter is to present the ATT's provisions for regulating in which situations arms exports will be prohibited.

Part III examines to what extent civil society plays an instrumental role in the pursuit and promotion of peace. This section underscores the significance of ensuring equal participation of racial/ethnic groups, refugees, and women in the promotion of peace. UN Security Council Resolution 1325 set out the perspective that the participation of women in peace negotiation and peacebuilding initiatives is considered to be essential. ${ }^{66}$ Yet, the majority of participants in peace talks continue to be men, To the extent gender issues are addressed, there has been in the past a disproportional focus on accountability for sexual violence compared to other issues, such as civic participation or guarantee of socio-economic rights, such as access to food, education, or housing. ${ }^{67}$ There is renewed attention on the importance of increasing the number of women mediators, but implementation remains slow. Critical analysis of compliance with UN Security Council resolutions and related output from UN institutions confirms Gina Heathcote's concern that implementation has had contradictory results, similar to Aolain and Haynes' concern that jus post bellum may 'cloak women's ongoing repression and inequality'.68

The challenge of pursuing equality requires a multilateral approach, as confirmed by the UN Secretary-General Antonio Guterres: 'Only by addressing the root causes of crisis, including inequality, exclusion and discrimination, will we build peaceful societies resilient to terrorism and violent extremism.' 69 In spite of the fact that equality and non-discrimination are identified as being central components of peace, there is great discrepancy between support for articulation of normative language and actual respect for norms in practice. The chapters examine the interface between law and politics as the quest for equality is increasingly challenged by resistance within society and state institutions. The need for a comprehensive approach to dismantle hierarchical, exclusionary structures which disempower vulnerable groups requires further research. The end of conflict presents quandaries for return, repatriation, and reintegration of

66 See: https://www.un.org/womenwatch/osagi/wps/ (accessed 19 June 2019).

67 P. Bukuluki et al., 'Negotiating Restorative and Retributive Justice in Access to Justice for Survivors of Sexual and Gender Based Violence in Post-conflict Northern Uganda', in Child Abuse and Neglect in Uganda, D. Kaawi-Mafigiri and E. Walakira (eds) (Springer International Publishing 2017), 201-25.

68 F. Aolain and D. Haynes, 'The Compatibility of Justice for Women with Jus Post Bellum Analysis' in Jus Post Bellum: Mapping the Normative Foundations, C. Stahn, J. Easterday, and J. Iverson (Oxford: Oxford University Press 2014); see also G. Heathcote, 'Women and Children and Elephants as Justification for Force', Journal on the Use of Force and International Law 4:1 (2017), 66-85; see also A. Goetz and R. Jenkins, 'Agency and Accountability: Promoting Women's Participation in Peacebuilding', Feminist Economics 22:1 (2016), 211-36; see also C. Bell and C. O'Rourke, 'Peace Agreements or Pieces of Paper? The Impact of UNSC Resolution 1325 on Peace Processes and their Agreements', International and Comparative Law Quarterly 59:4 (2010), 941-80; see also C. Chinkin and M. Kaldor, 'The Liberal Peace: Peacemaking, Peacekeeping and Peacebuilding' in C. Chinkin and M. Kaldor, supra note 4, 374-429.

69 https://www.un.org/sustainabledevelopment/blog/2018/01/un-chief-spotlights-potentialoffered-cooperation-among-countries-central-asia-afghanistan/ (accessed 19 June 2018). 
refugees and IDPs. ${ }^{70}$ Although host states are often eager to initiate return of refugees as soon as a peace accord is signed, this often proves problematic as refugees may be viewed as politically destabilizing to the home state, or this may worsen an IDP situation. Displaced people have enjoyed variable degrees of representation in peace processes, hence they may be included or excluded from voting on referendums or receiving compensation or restitution of property. ${ }^{71}$ Additionally, recent initiatives to place refugees in special economic zones, the privatization of detention centers, and the fact that host states may receive economic benefits on accounting of hosting refugees present dilemmas that require understanding of the role of international economic law. ${ }^{72}$

In Chapter 13, Vibeke Blaker Strand discusses the relationship between human rights norms pertaining to equality and non-discrimination, and peace. She argues that a society that is based on inequality and discrimination is not a society where people live peacefully together. It is not a society in peace. The term 'positive peace' rests on an understanding of peace that includes this broader picture, as it considers respect for human rights and social justice as components relevant to peace. Human rights norms on non-discrimination and equality can be seen as the twin of the notion of positive peace, the author argues, in that the aim behind these norms is not only to achieve formal equality, but substantive equality. The aim of the chapter is threefold. First, it explores the rich approach towards substantive equality that is embedded in international human rights conventions. This exploration involves both an individualistic approach towards substantive equality and a group-based approach. Secondly, it addresses some of the challenges that have been detected under the present international legal regime, and how the UN supervisory committees have responded to such challenges. Strand argues that the path towards substantive equality is characterized by the UN supervisory committees' dynamic interpretation in order to strengthen and develop the protection against discrimination and inequality. Thirdly, the chapter draws links between the legal sphere and the political struggles that have been, and are being, fought in this field.

In Chapter 14, Maja Janmyr explores how refugeehood is intrinsically linked to various aspects of peace. First, as is evidenced by the definition of 'refugee', refugees may be seen as consequences of breaches of peace. Secondly, the grant of asylum is a peaceful and humanitarian act that should not be regarded as unfriendly by another state. Thirdly, the linkage between refugees and (a lack of) peace is apparent in the reality in which refugee protection is deeply affected by greater security issues. Finally, the notion of peace is also relevant in discussions of durable solutions for refugees;

70 Mollie Gerver, 'Refugee Repatriation and the Problem of Consent', British Journal of Political Science (2016), 1-21; and Patricia García Amado, 'Connecting Tenure Security with Durable Solutions to Internal Displacement: From Restitution of Property Rights to the Right to Adequate Housing', International Migration 54:4 (2016), 74-86.

71 Maja Janmyr, 'Refugees as Contributors to Peace', Global Policy (6 June 2016), available at: http://www.globalpolicyjournal.com/blog/06/06/2016/refugees-contributors-peace (accessed 21 June 2018).

72 N. Hiemstra and D. Conlon, 'Beyond Privatization: Bureaucratization and the Spatialities of Immigration Detention Expansion', Territory, Politics, Governance 5:3 (2017), 252. 
repatriation, resettlement, and local integration all have the ultimate goal of allowing refugees to rebuild their lives in dignity and peace.

In Chapter 15, Cornelia Weiss analyzes the state of inclusion of women as peacemakers, peacekeepers, and peace-builders in law and practice. The chapter explores the status and effect of the Convention on the Elimination of All Forms of Discrimination Against Women and UN Security Council resolutions that address women peacemakers, peacekeepers, and peace-builders. It investigates compliance measures and addresses options to influence practice when the law does not. This chapter argues that the pursuit of peace is illusory without the inclusion of women.

Part IV explores peace as defined within UN Sustainable Development Goal \#16 which is dedicated to the promotion of peaceful and inclusive societies for sustainable development, the provision of access to justice for all, and building effective, accountable institutions at all levels. Collectively, the chapters give a nuanced reflection of the constraints faced by international governance institutions which require attention and further research.

This Part commences with a review of peacekeeping missions which have been criticized for contradicting the aim of consolidating peace and respecting human rights. ${ }^{73}$ There is a recent trend which has reduced the number of human rights officers within UN Blue Helmet peace operations, thereby decreasing the positive peace orientation, emphasizing negative peace. ${ }^{74}$ The chapter suggests that the peace pursued by peacekeepers is conceptually vague. This Part then continues with a discussion of fact-finding missions that are faulted for potentially masking the inability of the international system to respond to violations affecting peace.

This is followed by chapters pursuing an analysis of 'peace through justice' institutions, including truth commissions and international courts. ${ }^{75}$ What is the relationship between the pursuit of truth, justice, and accountability in the context of peace-building as a community interest? There is a challenge to respond to postconflict calls for accountability while maintaining peace by balancing use of traditional prosecution for war crimes with transitional justice mechanisms, such as truth commissions, and use of amnesties. Since Nuremberg, the approach of the international community has been to seek retribution - prosecution and punishment of perpetrators. In spite of an initial euphoria over the adoption of the Rome Statute, at present international criminal tribunals lack legitimacy because of selective prosecutions (largely directed at non-state actors or perceived as victor's justice). ${ }^{76}$ Both victims and

73 See John Karlsrud, 'UN Peacekeeping Missions Moving Toward "Chapter Seven and Half Operations"', IPI Global Observatory (12 February 2018).

74 R. Gowan, 'The Year Non-Western Powers Rewrote the Rules at the United Nations' in World Politics Review (2017); Xiaohong Xu, 'China's Engagement in African Security Affairs in the Post-Cold War Era', International Relations and Diplomacy 5:7 (July 2017), 412-25; Cedric de Coning, Chiyuki Aoi, and John Karlsrud (eds), UN Peacekeeping Doctrine in a New Era (Routledge 2017).

75 See C. Tams, World Courts as Guardians of Peace? (Centre for Global Cooperation Research 2016).

76 See Celestine Nchekwube Ezennia, 'The Modus Operandi of the International Criminal Court System: An Impartial or a Selective Justice Regime?', International Criminal Law Review 16:3 (2016), 448-79. 
witnesses state that they lack security guarantees, in the worst cases resulting in a need to seek asylum abroad. ${ }^{77}$ Further, international criminal courts are dependent on cooperation with national institutions for collection of evidence, delivery of arrest warrants, etc. This has proved to be difficult when domestic institutions are weak, in particular national courts may lack judicial independence, resources and personnel, there may be a backlog of cases, and problems with inefficiency and corruption. ${ }^{78}$ National jurisdictions are set within contexts in which power structures may not have been altered, in spite of peace accords. Hence, in Guatemala the trial of General Rios Montt on charges of genocide in Guatemala resulted in suspension. ${ }^{79}$ Furthermore, studies have shown that the ICC itself may not have directly deterred atrocities or war crimes, but instead indirectly prompted national prosecutions which may have some deterrence effect. ${ }^{80}$ Hybrid institutions, such as the Cambodian courts, suffer from corruption, delays, underfinancing, and similar problems which indicate that they may not necessarily enjoy greater legitimacy than international courts. ${ }^{81}$ There is a risk that trials actually may polarize post-transitional societies rather than promote peace. Truth commissions are often pursued as alternative to courts. They seek to provide an account of the past (hence responding to society's call for a right to the truth) or alternatively focus on reconciliation or pursue an investigation which may lead to future trials. Nevertheless, truth commissions are not a panacea; they may not necessarily be more successful meeting any of the general aims or at handling specific problems, such as addressing sexual violence cases, similar to courts. ${ }^{82}$

The Part then turns to examining the challenge of presenting politically sensitive cases within the dispute settlement system of the WTO, further illustrating both the potential and limitations of international governance institutions. It is notable that China highlights trade and investment as the path to attaining the UN Sustainable Development Goals, which include peace, in part framing its Belt and Road initiative as

77 See Tom de Boer and Marjoleine Zieck, 'ICC Witnesses and Acquitted Suspects Seeking Asylum in the Netherlands: An Overview of the Jurisdictional Battles between the ICC and Its Host State', International Journal of Refugee Law 27:4 (2015), 573-606, https://doi.org/10.1093/ ijrl/eev046.

78 See Annika Jones, 'Non-cooperation and the Efficiency of the International Criminal Court', in Cooperation and the International Criminal Court: Perspectives from Theory and Practice, O. Bekou and D. Birkett (eds) (Brill 2016), 185.

79 Sofia Menchu, 'Genocide Trial for Guatemala Ex-Dictator Rios Montt Suspended', Reuters (11 January 2016), available at: http://www.reuters.com/article/us-guatemala-trial-idUSK CNOUP21F20160111 (accessed 21 June 2018).

80 See the transitional justice database, available at: https://transitionaljusticedata.com/ (accessed 21 June 2018).

81 Ellen Emilie Stensrud, 'Transitional Justice and the Problem of Legitimacy. A Study of the Mixed Courts in Cambodia and Sierra Leone' (Phd thesis 2015).

82 Penelope Andrews, 'Justice, Reconciliation, and the Masculinist Way: What Role for Women in Truth and Reconciliation Commissions?', New York Law School Law Review 60:1 (January 12, 2016), available at SSRN: https://ssrn.com/abstract=2714490; and Louise Vella, 'Documenting Women's Experiences of Conflict and Sexual Violence: On the Ground with the Solomon Islands Truth and Reconciliation Commission', Transitional Justice in Practice (US: Palgrave Macmillan 2017), 141-69. 


\section{Research handbook on international law and peace}

the embodiment of this vision. ${ }^{83}$ There is a clear need for further research by scholars and practitioners from the East and the South. Addressing one of the most challenging areas of international cooperation in establishing accountability and governance institutions, the book examines Cyber Peace and the regional disagreement on the role of state and non-state actors in guaranteeing stability in cyberspace. The book then moves from the international level to the national level by returning to Kantian ideals of peace as being founded upon national constitutional instruments in a chapter which includes a call for recognition of human dignity as a fundamental element of peace. ${ }^{84}$ Finally, the epilogue advocates peace education as one of the most important strategies, indeed it has been characterized by the UN Secretary-General as the road to peace. ${ }^{85}$

In Chapter 16, Kjetil Mujezinović Larsen discusses the notion of 'peace' in international peace operations pursuant to a mandate from the United Nations Security Council. He assesses whether international law promotes or prevents the achievement of such peace. The chapter shows that international peace operations generally pursue 'liberal peace' and explain how this is translated into concrete functions within particular operations. Larsen argues that international law does little to promote peace through the creation of peace operations. Nevertheless, he suggests that international humanitarian law, international human rights law, and other regimes that regulate the conduct of personnel might contribute to the achievement of peace in peace operations.

In Chapter 17, Cecilie Hellestveit discusses various types of international fact-finding mechanisms and assesses their role in the promotion of negative peace. Hellestveit suggests that international fact-finding mechanisms have gained ground as tools by which the international community responds to man-made emergencies that may threaten peace, but they give rise to a number of dilemmas. The chapter asks a number of crucial questions in this regard: Do international fact-finding mechanisms serve to bemoan violations of international law while concealing inadequacies in international law's ability to respond to armed conflict and serious human rights abuse? Or is fact-finding an increasingly decisive component in the architecture of the international law of peace and its ability to contain, alleviate and ease recovery from armed conflict, responding to the predicament of fact-finding as 'a significant weapon in the armoury of world order'?

In Chapter 18, Jemima García-Godos addresses national and international efforts of post-conflict reconstruction and reconciliation in societies emerging from armed conflict or authoritarian regimes. Such efforts place great emphasis on the need for accountability for past human rights violations. The assumption behind these efforts is that justice must be addressed if the goal is a stable, long-lasting peace. Based on a discussion of victims' rights and the links between justice and peace, this chapter argues that transitional justice is a constitutive element of positive peace because it

83 Nicholas Rosellini and Laurence Brahm, 'Peace and Development with the Belt and Road Initiative', China Daily (9 February 2018). See also B. Goldsmith, 'Peace by Trade' in E. Bjarnegård and J. Kreutz, Debating the East Asian Peace (NIAS 2017).

84 On the link between constitutions and peace agreements see Christine Bell and Kimana Zulueta-Fuelscher, Sequencing Peace Agreements and Constitutions in the Political Settlement Process (International Institute for Democracy and Electoral Assistance 2016).

85 Ban Ki-moon, 'International Day of Peace: Education for Peace', 21 September 2013, http://www.un.org/en/events/peaceday/2013/sgmessage.shtml (accessed 20 June 2018). 
contributes to rebuild relations of trust in post-conflict societies. García-Godos discusses the main transitional justice mechanisms applied by countries seeking to establish some form of accountability for past violations: prosecutions, truth commissions, and victim reparations, providing examples from specific transitional justice experiences in Latin America.

In Chapter 19, Gentian Zyberi discusses the role and impact of international courts and tribunals in the promotion of peace. He argues that maintenance and restoration of peace is an essential community interest. It is clearly embedded in both treaty and customary international law and pursued through different institutional mechanisms and procedures; including international courts and tribunals. Courts can play an important role in maintaining or restoring interstate or intrastate peace, alongside existing non-judicial means, as well as methods of settling disputes that could endanger international peace and security. By settling interstate disputes, advising international organizations, or investigating and prosecuting those most responsible for having committed mass atrocity crimes, international courts and tribunals can potentially create the necessary conditions for the normalization of relations between states or between affected parts of a society in a post-conflict situation. The chapter discusses the role and contribution of principal international courts and tribunals, which through their case law have developed and interpreted important aspects of the scope of relevant legal obligations incumbent upon states, international organizations, and individuals. Despite their potential and eventual contribution, past and recent history shows that the role of courts in maintaining or restoring peace remains limited. Hence, this chapter addresses not only possibilities, but also institutional and other limitations related to the activity of courts which affect their potential contribution to peace.

In Chapter 20, Ole Kristian Fauchald discusses the important challenges currently facing the WTO dispute settlement mechanism, in particular the Appellate Body. He identifies a puzzle presented by the quest for a legitimate and effective dispute settlement mechanism against the call for promoting its relevance to peace. The underlying issue is that promoting its relevance to peace would inherently mean that it would play an important part in resolving politically sensitive disputes. He reviews WTO disputes and identifies 25 cases or clusters of cases that qualify as 'peacerelated'. Three case studies of the Ukraine-Russian conflict, Qatar's cases against Saudi Arabia, Bahrain and the United Arab Emirates, and disputes regarding US tariffs on imports of steel and aluminium show the relevance and challenges associated with resorting to the WTO dispute settlement mechanism in cases of serious conflicts or tensions between countries. Fauchald concludes that the dispute settlement mechanism may be perceived as enabling smaller states to control the acts of powerful states, but that the politicization of the selection of Appellate Body members may limit its ability to deal with politically sensitive cases.

In Chapter 21, Sean Kanuck examines the issue of cyber peace, discussing the dilemmas of attaining negative or positive peace and explaining the importance of technology. He describes a state of polarized divisions among nations regarding the aims of normative development and instead points to multi-stakeholder initiatives comprising members from industry, academia, non-governmental organizations (NGOs), and civil in the global cyber dialogue. He suggests that Pax technologica may only achieve negative 
peace, but that it is a prerequisite for pax informatica. He concludes that the international legal community should increase its competence in ICT and access to information, strategically linking cyber peace with sustainable development and human rights.

In Chapter 22, Azin Tadjdini addresses the constitutional dimension of peace. The chapter begins with the Kantian theory on constitutions as a prerequisite for peace. Having established the significant role of constitutions in this regard, the chapter continues with an analysis of peace promoting and peace threatening features in contemporary and past constitutions. The author argues that if we agree that the aim of peace is respect for each and every human being we can more easily identify constitutional features that are detrimental to peace, as these features will not see each human being as an end in itself. The chapter considers particularly three features: comprehensive doctrines, constitutional inequality and weak protection of human rights, and the lack of control mechanisms for impositions by the state. It is argued that a human-centric rather than state- or sovereign-centric constitution will in this regard be a more effective peace-promoting constitution.

In the epilogue, Juan Carlos Sainz-Borgo discusses the role of education for the creation of a culture of peace, further contemplating the role of law schools, and presents the approach pursued by the University for Peace. ${ }^{86}$

Even with this range of chapters, it must be acknowledged that the book does not cover a number of other issues that are also relevant to the promotion of peace in either the negative or the positive sense. For example, the book does not analyze the law of peace agreements. ${ }^{87} \mathrm{~A}$ more fundamental issue that is also omitted is the relationship between democracy and peace. It may be argued that a well-functioning democracy is a fundamental precondition for peace (taken together with economic interdependence and international cooperation to form the Kantian triad), yet there is already an impressive amount of literature within the social sciences testing this principle. ${ }^{88}$ Other issues omitted concern the international law of self-determination, secession, and the

86 See: https://news.un.org/en/story/2017/09/564492-high-level-forum-un-stresses-importanceeducation-building-culture-peace and https://www.upeace.org/ (accessed 20 June 2018).

87 For an analysis of peace agreements, see Christine Bell, On the Law of Peace: Peace Agreements and the Law Pacificatoria (Oxford: Oxford University Press 2008) and Christine Bell, Peace Agreements and Human Rights (Oxford: Oxford University Press 2000). See also the University of Notre Dame's Peace Matrix Database: https://peaceaccords.nd.edu/ (accessed 20 June 2018).

88 Examples of democracy and peace literature include Håvard Hegre, 'Democracy and Armed Conflict', Journal of Peace Research 51 (2014), 159-72; see also Margaret G. Hermann and Charles W. Kegley J., 'Democracies and Intervention: Is there a Danger Zone in the Democratic Peace?', Journal of Peace Research 38 (2001), 237; see also Christopher Layne, 'Kant or Cant: The Myth of the Democratic Peace', International Security 19:2 (1994), 5. On trade and peace, see Katherine Barbieri and Gerald Schneider, 'Globalization and Peace: Assessing New Directions in the Study of Trade and Conflict', Journal of Peace Research 36 (1999), 387, or Håvard Hegre, John R. Oneal, and Bruce Russett, 'Trade Does Promote Peace: New Simultaneous Estimates of the Reciprocal Effects of Trade and Conflict', Journal of Peace Research 47 (2010), 763. 
human rights of minorities and indigenous peoples. China has identified the three evils which threaten peace: terrorism, separatism, and exclusion. ${ }^{89}$ These issues interface with self-determination and minority rights and hence indicate a need for future research. Indeed, China's Belt and Road Initiative is framed as promoting a Pax Sinica which combines negative and positive components of peace, but also contains tensions and the possibility for contradictions as it merges counter-terrorism aims with peace: ${ }^{90}$

- Win-win cooperation

- Dialogue

- Respect for sovereignty, territorial integrity

- Cooperative security

- Mediation

- Counter-terrorism - addressing root causes

- Eradication of poverty and social injustice

This Research Handbook suggests that international law does not only promote peace through a topical and compartmentalized approach; it is international law as a whole, as a system, that promotes peace. There is a need to bolster recognition of the aim of peace as central to the function of international institutions and support further research as to how to buttress implementation in policy and practice. The chapters in this book should be regarded as a representative collection of relevant areas of international law, without any claim on behalf of the editors that these are the only topics of interest to peace research. Rather, the volume is to encourage other legal researchers to contemplate the link between their fields and the value of peace. Possible topics include: How do courts and other institutions construct, interpret, and implement the international law of peace? Is there a bias towards negative peace? What is the variable role of negative and positive peace within each field of law that may impact the construction of the international law of peace? To what extent is peace justiciable? Whether positive peace or sustainable peace can be implemented through normative or institutional reform within legal regimes? How is the international law of peace being constructed or deconstructed in an age of state-centric security? Which type of frameworks can promote positive Cyber Peace? What are the connections between peace, security, development, and human rights in policies on the prevention of violent extremism, post-conflict transformation, and institution building? Further, it is notable that there are a growing number of databases that provide a foundation for empirical studies: the Global Peace Index, the Positive Peace Index, PRIO's Gender, Peace, and Security Index, the Peace Accords Matrix of the University of Notre Dame, and the University of Edinburgh database for Women and Peace Agreements. Finally, the aim of this book

89 Enshen Li, 'China's New Counterterrorism Legal Framework in the Post 2001 Era: Legal Development, Penal Change, and Political Legitimacy', New Criminal Law Review 19 (Summer 2016), 344, 350 .

90 Speech by Xi Jinping at the opening of the Belt and Road Forum, May 2017, available at: http://www.bjreview.com/Documents/201705/t20170517_800096439_2.html (accessed 20 June 2018). 
is to call for a new consciousness to replace the dominant post-9/11 narrative of the 'War on Terror' within international law, instead seeking to revitalize the idea of researching international law and peace. 